\title{
FROM ZERO TOLERANCE TO HARM REDUCTION: "THE ASYLUM PROBLEM PROBLEM"
}

\author{
Desmond R. Manderson*
}

\begin{abstract}
The asylum problem is like the drug problem. This article explores the issues around Australia's treatment of asylum-seekers by developing this comparison with drug policy. Critically examining the logic and efficacy of policy, and the ways in which those ambitions are clouded by hysterical rhetoric and unrealistic expectations, the article develops parallels with the rhetoric and legal assumptions that have blighted drug policy for 100 years. At the same time, this parallel suggests an important way forward in both how policies are thought about and how they are explained to the public. What is critical about the drug debate is that there have been remarkable changes in direction over the past 10 years. Indeed, Australia has been at the forefront of those changes. The shift from "zero tolerance" to "harm reduction" has heralded a sea change in policy and in political discourse. Harm reduction strategies suggest a new model for how to rethink a policy agenda that is by any measure failing badly. What does the story of Australian drug policy teach us? What would a harm reduction approach to asylum-seekers look like? And how can we get there from here?
\end{abstract}

Keywords: asylum-seekers, drug policy, rhetoric, harm reduction

\section{Introduction}

For over a decade, many thousands of asylum-seekers have set out on the perilous ocean voyage from Malaysia and Indonesia to Australia; at least 1,000 have drowned in the attempt. The Australian Government has responded to the growth of irregular maritime arrivals (IMAs) through a series of increasingly draconian measures intended to stamp the traffic out. The latest policy development, announced in July 2013, sees Australia comprehensively outsourcing its responsibilities to them under the 1951 Geneva Convention Relating to the Status of Refugees - to Papua New Guinea, an exceedingly poor and dangerous country with significant refugee problems of its own. A massive advertising

\footnotetext{
* Professor, Australia National University, Canberra, Australia. An earlier version of this article was published as "Groundhog Day: Why the asylum problem is like the drug problem," in Griffith Review 41: Now We Are Ten, 2013, 84-110.
}

Refugee Survey Quarterly, Vol. 32, No. 4, pp. 1-21 $\quad$ (C) Author(s) [2013]. All rights reserved.

For Permissions, please email: journals.permissions@oup.com

DOI:10.1093/rsq/hdt019 
campaign bluntly declares, "If you come here by boat without a visa, you will never be settled in Australia".

The details of policy formation in Australia continue to change - almost on an hourly basis - as politicians from both the major parties attempt to "stop the boats" once and for all. But although the details of the current policy settings are variable, and the Federal election being held in September 2013 will no doubt bring further changes, the general tenor of Australia's approach has been consistent for several years under both major parties. Its central features include offshore processing, mandatory detention, a policy of "no advantage" intended to ensure that IMAs are no better off in Australia than in the transit countries from whence they came, and, under the Bali Process, aggressive interdiction activities aimed at suppressing "people smuggling" between the countries. These features are accompanied by a general assumption that the right outcome of policy and law must be to stop the boats once and for all. Anything else is considered a failure. It is with these general features that the current essay is concerned.

In researching the paradoxes and illogicality of these policy settings for this essay, I had something of an epiphany. The asylum problem is like the drug problem. ${ }^{2}$ Debate is framed in a moral language that excites a crisis completely unrelated to the dimensions of the problem. The asylum-seeker, like the drug addict, is depicted as a piteous victim who must be locked up for their own good; the "trafficker" or "smuggler" is considered a villain against whom no action is too harsh. Policies in both cases take a "zero tolerance" approach built around hugely expensive law enforcement strategies. The underlying assumption is that if only our laws are severe enough, people's behaviour will change. But the prohibition of drugs and the prohibition of boats make the same mistake. Supply-side responses to demand-side problems often fail to make real inroads into the underlying problems. Indeed, the case of drug policies demonstrates beyond all doubt that there are times when harsh law enforcement does not merely fail to stop the problem. It can actually make matters worse. Raising the stakes and driving people underground creates more profit, causes more deaths, and leads to more suffering. Unfortunately, rational arguments have little purchase in a climate fashioned by false assumptions as to what law can achieve, and a wilful blindness as to its unintended consequences.

In what follows, I explore the issues around Australia's treatment of asylumseekers by developing this comparison with drug policy. By and large, I seek to avoid claims based on human rights or even on compliance with established international norms. Important as those arguments are, I am more interested

1 See Australian Government, Department of Immigration and Citizenship (DIAC), Visas, Immigration and Refugees, Jul. 2013, available at: http://www.immi.gov.au/visas/humanitarian/novisa/ (last visited 30 Aug. 2013). For an example of the advertising campaign in all major Australian newspapers, see A. Lentin, "Refugees: A Call for Open Borders", The Guardian, 23 Jul. 2013, available at: http://www.theguardian. $\mathrm{com} / \mathrm{commentisfree/2013/jul/23/open-borders-australia-asylum-seekers} \mathrm{(last} \mathrm{visited} 30$ Aug. 2013).

2 For representative work, see D. Manderson, From Mr Sin to Mr Big: A History of Australian Drug Laws, Oxford, Oxford University Press, 1993; D. Manderson, "Possessed: Drug Policy, Witchcraft, and the Crisis of Belief", Cultural Studies, 19, 2005, 36-63; D. Manderson, "Substances as Symbols: Race, Rhetoric \& Tropes of Australian Drug History”, Social and Legal Studies, 6, 1997, 383-400. 
here in critically examining the logic and efficacy of policy, and the ways in which those ambitions are clouded by hysterical rhetoric and unrealistic expectations. These characteristics blighted the field of drug policy for a century.

My point is not simply that we have been down this path before, with disastrous results. What is critical about the drug debate is that, remarkably, something has changed in the past 10 years. Indeed, Australia has been at the forefront of that change. The shift from "zero tolerance" to "harm reduction" has heralded a sea change in policy and in political discourse. Harm reduction strategies suggest a new model for how to rethink a policy agenda, which is by any measure failing badly. What does the story of Australian drug policy teach us? What would a harm reduction approach to asylum-seekers look like? And how can we get there from here?

\section{A familiar rhetoric}

The so-called "war on drugs" featured a heightened moral rhetoric that long smothered it. Ever since anti-Chinese opium laws were enacted over 100 years ago, drug users have been portrayed as pitiable, weak, and doomed. "Why not just shoot them?" asked one member of the New South Wales Parliament in 1927. The then Premier regretted that while this "might be desirable [...] it is not done in civilised countries". ${ }^{3}$ One need only recall the United States (US) "documentary" Marijuana: Weed of Madness from the 1930s, or the hysteria surrounding marijuana use in the 1960s and 1970s. Salvation Army Major Brian Watters, principal adviser on illegal drug policy under Australian Prime Minister John Howard (1996-2007), declared that "there are worse things than death when it comes to addiction". Howard's period as prime minister marked the ascendancy of a "tough on drugs" policy that engaged in the "ruthless pursuit of drug importers, traffickers and dealers", as part of a "moral crusade" against illicit drugs. ${ }^{4}$

For many years, the moral rhetoric deployed against drug users generated intense social anxiety. Drugs were always out of control, always a new and "insidious threat to Australian society which has been unsurpassed in the country's history". Illicit drug use grew in Australia during the 1960s, as it did in the United Kingdom (UK) and other countries - notably cannabis use by young people and on a much smaller scale heroin use during and after the Vietnam War. But the hysteria that met this change was out of all proportion to the specific social and health problems it posed. It was, in a term introduced by Stanley Cohen in 1972, a "moral panic". ${ }^{6}$ In the grips of this moral panic,

3 Manderson, From $\mathrm{Mr}$ Sin to $\mathrm{Mr}$ Big, 95.

P. Mendes, "Social Conservatism vs. Harm Minimisation: John Howard on Illicit Drugs", Journal of Economic and Social Policy, 6(1), 2001, 3-6.

5 Manderson, From Mr Sin to Mr Big, 173.

6 S. Cohen, Folk Devils and Moral Panics, New York, MacGibbon and Kee, 1972; D. Garland, "On the Concept of Moral Panic", Crime Media Culture, 4(1), 2008, 9-30. 
morality and legality became hopelessly muddied. For many years, the illegality of certain drugs was justified because of their immorality, while their immorality was explained in terms of their illegality. Drug users were criminals because they were bad, and bad because they were criminals.

Similar confusions cloud the hyperbole around asylum-seekers. Leading politicians regularly condemn asylum-seekers - exercising their undoubted rights under international and domestic law - as "coming illegally to this country". Others speak less about a moral crusade than a moral dilemma: the harsh treatment of asylum-seekers is regrettable, but unavoidable. Nonetheless, there is a consistent moral language around questions of "fairness", "queue jumping", and "no advantage". As with drug traffickers, people smugglers are singled out for particular moral opprobrium. In 2009, Prime Minister Kevin Rudd (20072010, 2013) called them "vermin" and "the vilest form of human life". While the "user" of boats is imagined as the hapless victim of these evil smugglers, they are nonetheless portrayed as morally weak. In the immortal words of Nancy Reagan, they should "just say no".

Yet the language of morality and fairness is deeply misleading. Most IMAs currently come from a few countries including Afghanistan, Sri Lanka, Pakistan, Iraq, and Iran. These outflows are not a function of their lack of moral fibre or the trickery of smugglers, but directly related to insecurity, violence, and persecution in their countries of origin. ${ }^{10}$ The overwhelming majority of those who arrive in Australia, or are processed "off shore", are found to be genuine refugees - more than double the rate of those who apply for refugee status in other ways. In 2011-2012, the final grant rate for Afghani IMAs was 95.8 per cent, 93.1 per cent for Pakistanis, and over 90 per cent of all applicants. ${ }^{11}$

Indeed in the past few years the Australian Government has attempted to artificially reduce the number of accepted claims. In 2008-2009, only 189 IMAs were assessed; none was refused. But the following year, with boats on the rise, over a quarter of 2,826 refugee-status determinations were refused by the

7 M. Gordon, “Abbott Rules out Gay Union”, Sydney Morning Herald, 4 May 2013, available at: http://www. smh.com.au/national/abbott-rules-out-gay-unions-20130503-2iyo3.html (last visited 30 Aug. 2013).

8 K. Gelber, “A Fair Queue? Australian Public Discourse on Refugees and Immigration”, Journal of Australian Studies, 27(77), 2003, 19; S. Pickering, “'It Would be Okay If They Came through the Proper Channels': Community Perceptions and Attitudes toward Asylum Seekers in Australia”, Journal of Refugee Studies, 25(1), 2012, 113-133.

9 E. Rodgers, "Rudd Wants People Smugglers to 'Rot in Hell' ", Australian Broadcasting Corporation, 17 Apr. 2009, available at: http://www.abc.net.au/news/2009-04-17/rudd-wants-people-smugglers-to-rot-in-hell/ 1653814 (last visited 30 Aug. 2013).

10 Australian Government, Report of the Expert Panel on Asylum Seekers, Canberra, Government Printer, 2012, 59-63, available at: http://expertpanelonasylumseekers.dpmc.gov.au/report (last visited 30 Aug. 2013); M. Crock \& D. Ghezelbash, "Do Loose Lips Bring Ships? The Role of Policy, Politics and Human Rights in Managing Unauthorised Boat Arrivals", Griffith Law Review, 19(2), 2010, 238, 248-252.

11 Australian Government, DIAC, Humanitarian Program Outcomes 2010-11, Jul. 2011, available at: http:// www.immi.gov.au/media/statistics/pdf/humanitarian-program-outcomes-2010-11.pdf (last visited 30 Aug. 2013); Australian Government, DIAC, Asylum Statistics-Australia (Quarterly Tables), Mar. 2013, 14, available at: http://www.immi.gov.au/media/publications/statistics/asylum/_files/asylum-stats-march-quarter2013.pdf (last visited 30 Aug. 2013). 
Department of Immigration and Citizenship (DIAC). The following year, almost double the number of IMAs were processed, and this time close to two-thirds of the claims were refused. ${ }^{12}$ The more that applied, the higher the rejection rate. Australia's merits review process largely corrected this expedient trend. As the refusal rate went up, so did the rate at which those decisions were overturned. In recent years, the applications of fully three-quarters of those who were initially rejected have been upheld on appeal. ${ }^{13}$ In the March 2013 quarter, initial refusals had declined to about one third of primary decisions; but the overturn rate continued to be 70 per cent. ${ }^{14}$ The Shadow Minister for Immigration, Scott Morrison, commented that the figures "made a mockery of the initial assessment of asylum claims". ${ }^{15}$ True, but the scandal lies not in the dishonesty of IMAs or the gullibility of the Refugee Review Tribunal. The scandal lies in the department's expedient reluctance to recognize genuine claims for refugee status. If magistrates' decisions were being overturned at anything even remotely approaching such a rate, the legal system would be in uproar. The fault would surely not lie with appeals courts, which exist to correct initial errors.

So too the moral rhetoric of the "queue" is nonsense. Australian embassies overseas will not accept direct applications from refugees. In some countries there are no diplomatic missions; in Afghanistan, the location of the Australian consulate is a secret. Australian airlines will not let anyone board a plane without a valid visa. Meanwhile, the United Nations High Commissioner for Refugees (UNHCR) - the "proper channels", so to speak - is swamped. In 2009 , only 119,100 applications were registered out of 923,400 new claims. On top of this, barely one per cent of registered refugees are resettled in new host countries in any one year. ${ }^{16}$ Consequently, waiting times are extreme throughout the Asia-Pacific region, and the chance of being eventually resettled in Australia or a comparable country has become statistically remote.

12 Australian Government, DIAC, Fact Sheets \#1-87, \#60-69, available at: http://www.immi.gov.au/media/factsheets/ (last visited 30 Aug. 2013); Australian Government, DIAC, Asylum Trends-Australia, Canberra, Government Printer, 2011, 30, available at: http://www.immi.gov.au/media/publications/statistics/asylum/_ files/asylum-trends-aus-annual-2010-11.pdf (last visited 30 Aug. 2013); J. Phillips, "Asylum Seekers and Refugees: What are the Facts?”, Parliamentary Library Background Note, Parliament of Australia, Feb. 2013, fn 39-55, available at: http://www.aph.gov.au/About_Parliament/Parliamentary_Departments/ Parliamentary_Library/pubs/BN/2012-2013/AsylumFacts (last visited 30 Aug. 2013).

13 Australian Government, DIAC, Asylum Trends-Australia, 30-34; Australian Government, DIAC, Asylum Trends-Australia, Canberra, Government Printer, 2012, 30-33.

14 Australian Government, DIAC, Asylum Statistics—Australia (Quarterly Tables), Mar. 2013, 11-14, available at: http://www.immi.gov.au/media/publications/statistics/asylum/_files/asylum-trends-aus-annual-2011-12. pdf (last visited 30 Aug. 2013).

15 J. Owens, "Rejected Boat People Sail through Tribunal", The Australian, 18 Mar. 2013, available at: http:// www.theaustralian.com.au/national-affairs/immigration/rejected-boatpeople-sail-through-tribunal/storyfn9hm1gu-1226599409100 (last visited 30 Aug. 2013).

16 UNHCR, Global Trends 2011 (A Year of Crises), Geneva, UNHCR, 3-7, 24, available at: http://www.unhcr. org/4fd6f87f9.html (last visited 30 Aug. 2013); E. Karisen, "Refugee Resettlement to Australia: What are the Facts?", Parliamentary Library Background Note, Parliament of Australia, Dec. 2011, 3-4, available at: http:// parlinfo.aph.gov.au/parlInfo/download/library/prspub/1276913/upload_binary/1276913.pdf (last visited 30 Aug. 2013). 
Neither is the recent surge of IMAs to Australia a crisis. In absolute terms and in relation to the global population of concern, the number of people we are talking about is still relatively small. Despite growing numbers, particularly over the past 2 years, refugees remain overwhelmingly a Third World problem. Australia's 2012 asylum population of 23,434 is equivalent to one for every 1,000 citizens (compare US 0.9, UK 3.8, Germany 7.2, Iran 14.5, or Syria 49.3). This puts Australia 71 st in the world. There are 1.7 million refugees in Pakistan, almost a million in Iran and in Syria, and several hundred thousand in South Africa; the city of Dadaab in Kenya alone houses 559,000 registered refugees. ${ }^{17}$ Looked at more broadly, in 2011, Australia received around 15,000 asylum applications, or less than a per cent (ranked 32nd per capita) of the 1.6 million applications globally. ${ }^{18}$ Of industrialised countries, Australia was responsible for 3 per cent of applications, which ranked 18th per capita. ${ }^{19}$

Currently hovering around 10 per cent, Australia's humanitarian intake is in fact a smaller proportion of its migration programme than during most of its recent history. ${ }^{20}$ In 1948-1949, Australia accepted 33,816 refugees (almost a third of Australia's total migrant intake that year) - the next year 89,199 refugees made up fully half the total number of migrants, and the following year the 36,912 refugees represented a quarter of all immigrants. Again in the years 1979-1985, Australia accepted between 15,000 and 20,000 Vietnamese boat people annually, around 20 per cent of the migrant intake in each of those years. ${ }^{21}$

Moreover, in the five-year period 2007-2012, ${ }^{22}$ despite the fact that the language of crisis was being deployed on all sides, the figure of 13,000 people taken under Australia's Humanitarian Programme remained unchanged. ${ }^{23}$ Increasing numbers of IMAs were entirely off-set by reductions to other parts of the programme. As on-shore migration (including maritime arrivals) increased, other parts of the programme - notably the Special Humanitarian Programme, which allows Australian residents to bring in family members facing

17 UNHCR, Global Trends 2011; Australian Government, Report of the Expert Panel on Asylum Seekers, 61-63; Refugee Council of Australia, National and Global Statistics 2013-14, 2013, 14, available at: http://www. refugeecouncil.org.au/r/isub/2013-14-IntakeSub-stat.pdf (last visited 30 Aug. 2013).

18 Refugee Council of Australia, National and Global Statistics 2013-14, 17; Australian Government, Report of the Expert Panel on Asylum Seekers.

19 UNHCR, Asylum Levels and Trends in Industrialized Countries, Geneva, UNHCR, 2011, 20, available at: http://www.unhcr.org/4e9beaa19.html (last visited 30 Aug. 2013); Phillips, "Asylum Seekers and Refugees"; Australian Government, DIAC, Asylum Trends-Australia, 2-3.

20 Refugee Council of Australia, National and Global Statistics 2013-14, 7.

21 Refugee Council of Australia, National and Global Statistics 2012-13 and 2013-14, 7-8.

22 Australian Government, Report of the Expert Panel on Asylum Seekers, 14; Australian Government, DIAC, Humanitarian Program Information Paper 2013-14, Dec. 2012, 2, available at: http://www.immi.gov.au/ media/publications/pdf/humanitarian-program-information-paper-2013-14.pdf (last visited 30 Aug. 2013); J. Gillard \& C. Bowen, "Refugee Program Increased to 20000 Places", Media Release, 23 Aug. 2012, available at: http://www.minister.immi.gov.au/media/cb/2012/cb189459.htm (last visited 30 Aug. 2013).

23 Refugee Council of Australia, National and Global Statistics 2013-14, 4; Australian Government, DIAC, Fact Sheet 60; Australian Government, DIAC, Asylum Trends-Australia. 
human rights abuse abroad - were reduced by the same amount. ${ }^{24}$ As a direct result, the programme now faces a backlog of over 20,000 applicants, who face a wait of many years to bring endangered family members to join them in Australia. This linkage has had no discernible impact on the number of IMAs. As with many ill-thought out deterrents, however, it did fall foul of the rule of unintended consequences. In 1999, when linkage was first introduced, children made up only 13 per cent of asylum-seekers. By 2001, faced with the risk of never being able to bring their families out, the proportion of children on boats had risen to a third. ${ }^{25}$ Even DIAC now acknowledges that more families began to arrive by boat due to the lack of family reunion options. ${ }^{26}$ In October 2001, the SIEV-X disaster claimed the lives of 65 men, 142 women, and 146 children. ${ }^{27}$ Yet since August 2012 the Australian Government has once again denied IMAs any right to access the split family programme. ${ }^{28}$ Not only will this surely increase the number of families on boats again; the policy will hit unaccompanied minors hardest of all.

In a response to a largely manufactured panic, Australia endured no less than eight royal or parliamentary commissions into drugs and drug trafficking between 1971 and 1983. The best of them, including the South Australian Royal Commission into the Non-Medical Use of Drugs, ${ }^{29}$ insisted that the major drug problems in Australian society lay not with illicit drugs but on the contrary with the use and abuse of legal drugs, including alcohol, tobacco, and pharmaceuticals. In 1977, the Senate Standing Committee on Social Welfare produced a celebrated report entitled Drug problems in Australia - an intoxicated society? Senator Peter Baume, its chair, argued that Australia did not have a "drug problem" but a "drug problem problem"; ${ }^{30}$ not a social or a health crisis but a crisis in how we framed and talked about an important but by no means unmanageable issue.

So too, Australia does not have an asylum problem. It has an "asylum problem problem", a crisis of language and perception. So long as the drug issue was framed as a crisis undermining the very fabric of our society, politicians

24 Refugee Council of Australia, National and Global Statistics 2013-14, 4; Australian Government, DIAC, Fact Sheet 60; Phillips, "Asylum Seekers and Refugees".

25 Crock \& Ghezelbash, "Do Loose Lips Bring Ships?”, 262.

26 Senate Legal and Constitutional Affairs Legislation Committee, Immigration and Citizenship Portfolio, Supplementary Budget Estimates, Parliament of Australia, 17 Oct. 2011.

27 M. Hutton, "Drownings on the Public Record of People Attempting to Enter Australia Irregularly by Boat 1998-2012", 2011-2013, available at: http://sievx.com/articles/background/DrowningsTable.pdf (last visited 30 Aug. 2013); T. Kevin, Reluctant Rescuers, Canberra, Union Offset, 2012, 143.

28 Australian Government, DIAC, Humanitarian Program Information Paper 2013-14, 3-4; C. Bowen, "Government Implements Expert Panel's Family Reunion Recommendation", Media Release, 22 Sep. 2012, available at: http://www.minister.immi.gov.au/media/cb/2012/cb190059.htm (last visited 30 Aug. 2013)

29 South Australia, Royal Commission into the Non-Medical Use of Drugs, Adelaide, Government Printer, 1979.

30 Senate Standing Committee on Social Welfare, Drug Problems in Australia - An Intoxicated Society?, Canberra, AGPS, 1977; discussed in Manderson, From Mr Sin to Mr Big, 170; see also R. Marks, “A Freer Market for Heroin in Australia”, Journal of Drug Issues, 20(1), 1990, 131-176, 132-133. 
saw little mileage in trying to defuse the issue. To be "against" law and order was a losing proposition. By the same token, for as long as the asylum issue is framed as a crisis undermining the very cohesion of our society, politicians see little mileage in trying to defuse the issue. To be "against" border protection is equally a losing proposition.

\section{Zero tolerance}

\subsection{A counter-productive logic}

In relation to both drug and asylum issues, moral panic has led to uncannily similar legal responses. The "drug problem problem" led to draconian legislation, increased law enforcement, and the criminalisation of growing numbers of drug users. The courts faced an endless procession of young people from all walks of life facing the lasting stigma of a criminal conviction. Yet laws that prohibit drug use make little inroad into underlying levels of use or addiction. Cannabis and heroin use grew steadily through the 1970s and 1980s. Illicit drugs are today as widely used and as easily accessible as they have ever been. ${ }^{31}$ Even government inquiries such as those in Canada and South Australia conceded as much. ${ }^{32}$ In recent years, their arguments have been bolstered by a parade of former premiers and government ministers, retired police commissioners, and weary public health officials, all bemoaning the unwinnable war in which they have been conscripted.

With certain kinds of problems, a kind of legal magic realism sets in. The assumption is that if only deterrents are made severe enough, people will change their behaviour. So if a policy centred on law enforcement fails, the solution is assumed to lie in more law enforcement and heavier deterrents. Alfred Conroy, a founding member of the Commonwealth Liberal Party, doubted the viability of this reasoning during Australia's first Federal parliamentary debate on drug laws: "We are assuming that all we have to do is to pass an Act of Parliament when, hey presto, all sin and misery will disappear from the world [...] [We are] ready to pass an Act for the prohibition of the opium traffic in the full belief that the evil will at once disappear". ${ }^{33}$ That was 1905 .

Crucially, these laws have not just been ineffective. They have had terrible consequences. Prohibition is not regulation; it is the opposite of regulation. Regulation works to the extent that it allows some level of social activity to continue; it becomes counter-productive when it drives users underground. Thus, in relation to alcohol and tobacco, we see a range of licensing controls,

31 R. Douglas \& D. McDonald, The Prohibition of Illicit Drugs is Killing and Criminalising Our Children: (Australia 21 Report), Sydney, Australia 21 Limited, 2012, 12-14, available at: http://www.australia21.org. au/publications/press_releases/12/Sep/75249438d22e61ad69cda2008669d88b.pdf (last visited 30 Aug. 2013); Australian Institute of Health \& Welfare, Drugs in Australia 2010: Tobacco, Alcohol and Other Drugs, Drug Statistics Series No. 27, Canberra, AGPS, 2011.

32 Canada, Commission of Inquiry into the Non-Medical Use of Drugs, Ottawa, Government Printer, 1972; South Australia, Royal Commission into the Non-Medical Use of Drugs.

33 In Manderson, From Mr Sin to Mr Big, 43. 
plain packaging laws, and so on, which limit the harms associated with these drugs precisely by adopting a regulatory approach. On the other hand, the terrible harms of un-regulation we know from the most notorious experiment of them all, the era of "Prohibition" in the US. Gangsters such as Al Capone had a field day; violence and corruption flourished as never before. Alcohol prohibition was a short-lived failure. Drug prohibition - introduced in the US in 1914 and soon exported around the world - has a longer but no less inglorious history. Policies directed at criminalising users and demonising traffickers do not stop drug use and have only a minor and temporary effect on drug importation. But the riskier it is, the higher the profits made by drug traffickers, and the more dangerous the conditions under which drugs are used.

The result is that drug prohibition is itself responsible for the very problems that it claims to address. ${ }^{34}$ As opposed to alcohol and tobacco, virtually no illicit drug-related deaths in Australia are attributable to drug use as such. People die not because they inject heroin but because of the conditions under which they take it - conditions created by the legal framework itself. Illegal use ensures that dosages are unpredictable. A heroin user might consume a dangerously pure dose one time and a cocktail of toxins the next. The secretive conditions of illegality ensure that there is no medical or social support for the user. When users cannot legally obtain clean needles, they share dirty ones, spreading diseases such as Hepatitis C and HIV-AIDS. In our inner cities, the criminal nature of the enterprise does not discourage traffickers - far from it - but sometimes leads to dangerous turf wars. In many Latin American countries, escalating drug wars have corrupted the social and political structure, with devastating results ${ }^{35}$ - over 28,000 deaths in Mexico alone. Drugs are not the cause of these harms; their (il)legal status is.

The relation between harm, deterrence, and counter-productive consequences is more complicated in relation to asylum policy, but the lesson is the same. One of the main harms in question is the issue of deaths at sea. Over 1,000 asylum-seekers have died en route to Australia since 2001. The SIEV X disaster took 353 lives; the loss of the Barokah off the coast of East Java in December 2011, 200 more. ${ }^{36}$ Yet these deaths are clear instances of harms caused by the legal framework. The legal distinction between signatory and non-signatory countries in the region makes Australia an attractive destination for asylumseekers, while making it harder for our Government to return them to countries that lack similar legal protections. ${ }^{37}$ Furthermore, asylum-seekers use boats because Australia aggressively prevents their arrival by other means. The

\footnotetext{
34 R. Douglas, A. Wodak \& D. McDonald, Alternatives to Prohibition: (Australia 21 Report), Sydney, Australia 21 Limited, 2012; R. Marks, "Prohibition or Regulation: An Economist's View of Australian Heroin Policy", Australian and New Zealand Journal of Criminology, 23(2), 1990, 65-87; J. Miron, Drug War Crimes: The Consequences of Prohibition, Oakland, Independent Institute, 2004.

35 M. Linton, Cocaina, Brunswick, Scribe Publications, 2013.

36 Hutton, "Drownings on the Public Record".

37 M70/2011 v. Minister for Immigration and Citizenship, [2011] HCA 32 (High Court of Australia).
} 
Government will not accept refugee applications in its consulates or embassies. It will not accept on its aircraft anyone without a valid visa or even with a visa if they intend to make a refugee claim on landing. As James Hathaway wrote, "if you could lawfully come to Australia and make a refugee claim without the need of sneaking in with a boat, people would do it. But we make it illegal and create the market that smugglers thrive on". ${ }^{38}$

Two extreme responses come to mind. The first would be to withdraw from the Refugee Convention. ${ }^{39}$ Yet although the Refugee Convention is proving an increasingly unwieldy instrument, it does accomplish something important. Its signatories are typically developed countries; the burdens of irregular migration fall overwhelmingly on developing countries. Without it, those burdens would be even more unequal. In an increasingly globalised world, we can run but we cannot hide. ${ }^{40}$ The Phoenicians, said Arthur Koestler, used to beat the waves to calm the storm. Withdrawing from the Refugee Convention would be a similar exercise in futility.

The second response would take the opposite approach. The less distinction between the treatment of refugees in different countries, the less reason asylumseekers have to move. In 2011, the High Court of Australia struck down the federal Government's "Malaysia solution", for complex reasons but basically because Malaysia was not a signatory to the Refugee Convention. ${ }^{41}$ If laws were in place there that adequately protected refugees, Australia could legally accept larger numbers of refugees from transit countries in exchange for returning IMAs there. As opposed to the Australian Government's Papua New Guinea solution, which outsources the resettling of IMAs to third parties even poorer and more vulnerable than Malaysia, a swap between transit countries and IMAs would place no additional burdens on any other country.

Transit countries are of course reluctant to sign the Refugee Convention because of the weighty obligations that it imposes. But in the long run such developments are not inconceivable. After all, the need to find real solutions is even more pressing in Malaysia and Indonesia than in Australia. Over the next few years it may come to seem only practical for these countries to accept greater domestic legal obligations in exchange for a substantially expanded contribution from Australia. Both sides are being inexorably driven into each other's arms. What largely stands in the way is not the asylum problem, but the asylum problem problem.

\footnotetext{
38 J. Hathaway, Australian Broadcasting Corporation, 'RN Breakfast', 20 Sep. 2011; J. Hathaway, "The Human Rights Quagmire of 'Human Trafficking'", Virginia Journal of International Law, 49, 2008, 1-59.

39 See A. Millbank, "The Elephant on the Boat: The Problem that is the Refugee Convention", People and Place, 18(4), 2010, 41-49.

40 C. Dauvergne, Making People Illegal: What Globalization Means for Migration and Law, Cambridge, Cambridge University Press, 2008.

41 M70/2011 v. Minister for Immigration and Citizenship [2011] HCA 32.
} 


\subsection{Deterrence and unintended consequences}

Since the Convention was drafted 60 years ago, the number of refugees has grown fifteen-fold. This is of course placing enormous strains on the resources of transit countries. In Indonesia, for example, where there are about 6,000 asylum-seekers and recognized refugees, resettlement lags well behind arrivals. ${ }^{42}$ Meanwhile refugees find themselves in a state of limbo; children get no schooling, adults cannot work. ${ }^{43}$ The situation in Malaysia is far worse. There are now 86,680 refugees and 10,937 asylum-seekers, together with a further 120,000 irregular migrants, ${ }^{44}$ similarly unprotected and vulnerable. It is hardly surprising, then, that many should look for a safer haven.

Australian policy is framed around attempting to deter as many of them as possible. But, as we have seen in relation to drug policy, we should be sceptical of the effectiveness of deterrence measures. "Push factors" that drive asylum-seekers out of their own countries and away from transit countries are largely global in nature; "pull factors" that might draw them to Australia (as opposed to elsewhere), including its reputation as a prosperous and tolerant country, are likewise largely out of its control. Specific policies have little impact - governments and international organizations are simply not trusted by the people they are trying to reach; dissemination strategies are inadequate; and there are serious practical barriers in terms of translation, literacy, and access. ${ }^{45}$

After an extensive analysis, economist Timothy Hatton concluded that the treatment of asylum-seekers once they have reached their destination country has "little deterrent effect". 46 Perhaps the poster child for the failure of in-country deterrence is Australia's policy of mandatory detention. In February 2013, 4,526 people were being held in immigration detention on the Australian mainland and 1,224 in detention on Christmas Island. ${ }^{47}$ This includes over 1,000 children, not counting those currently held in "regional processing centres" on Manus Island or Nauru. Since legislation passed in $1992,{ }^{48}$ supposedly "for a

42 UNHCR, Indonesia, 2013, available at: http://www.unhcr.org/pages/49e488116.html (last visited 30 Aug. 2013); Crock \& Ghezelbash, "Do Loose Lips Bring Ships?”, 270; S. Taylor \& B. Rafferty-Brown, "Waiting for Life to Begin: the Plight of Asylum Seekers Caught by Australia's Indonesian Solution”, International Journal of Refugee Law, 22(4), 2010, 558-592.

43 S. Taylor \& B. Rafferty-Brown, "Difficult Journeys: Accessing Refugee Protection in Indonesia", Monash University Law Review, 36(3), 2010, 138.

44 UNHCR, Malaysia.

45 K. Koser, Responding to Boat Arrivals in Australia: Time for a Reality Check, Sydney, Lowy Institute, 2010, 8-9, available at: http://lowyinstitute.org/files/pubfiles/Koser\%2C_Responding_web.pdf (last visited 30 Aug. 2013).

46 T. Hatton, “The Rise and Fall of Asylum: What Happened and Why?", The Economic Journal, 119(535), 2009, F183, F209.

47 Australian Government, DIAC, Immigration Detention Statistics Summary, Feb. 2013, 3, available at: http:// www.immi.gov.au/managing-australias-borders/detention/_pdf/immigration-detention-statistics-feb2013. pdf (last visited 30 Aug. 2013).

48 Migration Reform Act 1992 (Commonwealth of Australia); Crock \& Ghezelbash, "Do Loose Lips Bring Ships?", 255-257. 
limited period", ${ }^{49}$ all unauthorized arrivals are kept under conditions of isolation and hardship for years at a time and at a cost to the Australian taxpayer of over $\$ 700$ million per year. The policy inflicts psychological and physical harm, sickness, suffering, and death on those who have committed no crime other than to claim their rights under international law. ${ }^{50}$ Yet mandatory detention has had no discernible impact on rates of IMAs over the years. ${ }^{51}$

The flawed notion that government can "send a message" to future asylumseekers - to scare them off as it were - by treating those who make it here with exemplary severity, continues to befuddle the debate. On 21 November 2012, the minister for immigration announced a new category of bridging visas designed to reduce the pressure on Australia's overcrowded detention facilities. The Minister, Chris Bowen, announced: "Consistent with 'no advantage', people from this cohort going onto bridging visas will have no work rights and will receive only basic accommodation assistance, and limited financial support". ${ }^{52}$ Not only will this policy do nothing to discourage asylum-seekers coming to Australia; like many other examples of the logic of prohibition, it will have appallingly counter-productive effects. ${ }^{53}$ The case study of drug policy reminds us that prohibition is not regulation; it is un-regulation. Despite the law, visaholders will certainly work; on $\$ 30$ a day, how could they survive otherwise? As with drug policy, what will change is not the practice but the conditions. Those on a bridging visa will be paid under the table, contribute no tax, and undercut Australian workers. They will work on the margins of society, some no doubt as prostitutes, some in the drug trade. All of them will be condemned to poverty and vulnerable to exploitation and blackmail. ${ }^{54}$ And just as with drug policies, they will be blamed for the inevitable consequences of the legal framework the Australian Government itself set up. Opposition spokesman Scott Morrison, for example, recently demanded that asylum-seekers should not be released into the community without special "behaviour protocols" and the notification of police

49 Second reading speech by G. Hand, in J. Phillips \& H. Spinks, "Immigration Detention in Australia", Parliamentary Library Background Note, Parliament of Australia, Mar. 2013, fn 137, available at: http://www. aph.gov.au/About_Parliament/Parliamentary_Departments/Parliamentary_Library/pubs/BN/2012-2013/ Detention (last visited 30 Aug. 2013).

50 R. Manne, Sending Them Home: Refugees and the New Politics of Indifference, Sydney, Black Books, 2003; Phillips \& Spinks, "Immigration Detention in Australia"; K. Bem et al., A Price Too High: The Cost of Australia's Approach to Asylum Seekers, Sydney, A Just Australia and Oxfam Australia, 2007, available at: http://www.ajustaustralia.com/resource.php?act=attache\&id=213 (last visited 30 Aug. 2013); M. Welch, "Quiet Constructions in the War on Terror: Subjecting Asylum Seekers to Unnecessary Detention", Social Justice: A Journal of Crime, Conflict \& World Order, 31, 2004, 113-129.

51 J. Menadue et al., A New Approach: Breaking the Stalemate on Asylum Seekers and Refugees, Sydney, Centre for Policy Development, 2011, 13, 21, 31, available at: http://cpd.org.au/wp-content/uploads/2011/08/cpd refugee_report_2nd-run-WEB-VERSION3.pdf (last visited 30 Aug. 2013); Phillips \& Spinks, "Immigration Detention in Australia".

52 C. Bowen, "No Advantage On Shore for Boat Arrivals", Media Release, 21 Nov. 2012, available at: http:// www.minister.immi.gov.au/media/cb/2012/cb191883.htm (last visited 30 Aug. 2013).

53 G. Marston, Temporary Protection, Permanent Uncertainty: The Experience of Refugees Living on Temporary Protection Visas, Melbourne, Centre for Applied Social Research, RMIT University, 2003; P. Mathew, Reworking the Relationship between Asylum and Employment, London, Routledge, 2012.

54 Marston, Temporary Protection, Permanent Uncertainty. 
and residents in the area. ${ }^{55}$ Illicit drug laws turned thousands of young people into criminals, and their criminality was then cited to justify ever harsher laws that stigmatised more and more of them. These laws will follow the same counter-productive spiral.

The central platform of Australian deterrence policy is the establishment of off-shore "regional processing centres" supported by a "no advantage" test. ${ }^{56}$ Yet given continuing demand pressures, this policy is already overloading the makeshift facilities Australia has set up. Amnesty International describes conditions on Nauru as "a human rights catastrophe [...] a toxic mix of uncertainty, unlawful detention and inhumane conditions". ${ }^{57}$ No doubt immediate problems can be addressed, at least to some extent. What cannot be fixed is the logic. ${ }^{58}$ The same pressures that drive refugees from Afghanistan or Sri Lanka to Malaysia and Indonesia will continue to drive them to Australia, where they will be housed off-shore at hideous expense and with increasing harm to Australia's reputation. Despite the Government's recent dogmatic assertion that boat arrivals "will never be settled in Australia", it is hard to see how this can be true. Of the asylumseekers sent to Nauru under the so-called "Pacific Solution" (2001-2007), 586 were granted Australian resettlement, 360 resettled in New Zealand, and a mere 33 were resettled elsewhere. ${ }^{59}$ New Zealand has already indicated that it will take only half as many this time around. So the burden of resettlement will continue to fall on Australia.

Two things must follow. Either material and psychological pressures in these places will become so intolerable that resettlement will take place sooner, via bridging visas or otherwise. Ironically that is one reason why the boats keep coming - the more that come, the more pressure there will be to find an alternative. Again our policies have exactly the opposite results than intended. Or there will be a delay of several years, in which case the facilities will get more and more overcrowded and dangerous. Recent riots in Nauru demonstrate the likelihood of this particular outcome. Indeed, in 2005, the Australian Government surreptitiously resettled all remaining detainees still held on Manus Island and

55 L. Taylor \& J. Ireland, “Libs Push for Asylum Crackdown”, The Age, 28 Feb. 2013, available at: http://www. theage.com.au/federal-politics/political-news/libs-push-for-asylum-crackdown-20130227-2f6er.html (last visited 30 Aug. 2013).

56 Australian Government, DIAC, Humanitarian Program Information Paper 2013-14; Migration Legislation Amendment (Regional Processing \& Other Measures) Act 2012 (Commonwealth of Australia); C. Bowen, "Nauru Designated for Regional Processing", Media Release, 10 Sep. 2012, available at: http://www.minis ter.immi.gov.au/media/cb/2012/cb189739.htm (last visited 30 Aug. 2013).

57 Amnesty International, Nauru Camp: A Human Rights Catastrophe With No End In Sight, Nov. 2012, 1, available at: http://www.amnesty.org/en/library/asset/ASA42/002/2012/en/33cb74aa-5d53-4ed2-80a4df9d4965485e/asa420022012en.pdf (last visited 30 Aug. 2013).

58 See J. Hathaway, “The False Panacea of Offshore Deterrence”, Forced Migration Review, 26, 2006, 56-57.

59 Human Rights and Equal Opportunities Commission (Australia) (HREOC), Submission of the Human Rights and Equal Opportunity Commission to the Senate Legal and Constitutional Legislation Committee on the Migration Amendment (Designated Unauthorised Arrivals) Bill 2006, Sydney, HREOC, May 2006, 4.12, available at: http://www.humanrights.gov.au/submission-migration-amendment-designated-unauthorised-ar rivals-bill-2006 (last visited 30 Aug. 2013). 
Nauru, apparently in response to an independent report that expressed alarm at their deteriorating mental health. ${ }^{60}$

This is not to say that deterrence never works. Hatton concluded that policies have a deterrent effect when directed towards "access to the country's territory in order to establish a claim for asylum" and "the toughness of the refugee status determination procedure". The Pacific Solution accomplished the latter in a roundabout way. There were 1,637 asylum-seekers processed; 1,153 were resettled; the rest were denied status as refugees and sent home. ${ }^{61}$ But as the Human Rights and Equal Opportunity Commission (now the Australian Human Rights Commission) noted in 2006, asylum-seekers processed offshore at that time had no access to an independent merits review. ${ }^{62}$ Indeed, the 30 per cent rejection rate is uncannily similar to the DIAC's own primary refusal rate in recent years. As we know, in Australia close to three-quarters of those initial refusals are overturned on appeal. So if the Pacific Solution took any pressure off Australia, it is clear how - the lack of an adequate review procedure almost certainly sent back genuine refugees in order to keep the numbers down. Such a denial of right would be difficult to justify publicly, even in Australia. Indeed, the failure to provide a proper determination procedure would itself place us in breach of our international obligations. Consequently, refugee legislation in Nauru and Papua New Guinea now allows for both independent merits review and judicial review. ${ }^{63}$

The Pacific Solution also made access to Australian territory more difficult. It did so by a combination of interception on the high seas, the legal excision of places like Ashmore Reef and Christmas Island from the Australian mainland, and off-shore processing. While this is frequently credited with drastically reducing the number of boats that came to Australia after 2001, certain caveats need to be entered. Correlation does not establish causation. It is unclear to what extent changing "push factors" (such as the fall of the Taliban) were ultimately responsible for a decline in IMAs. As the Secretary of DIAC conceded before the Senate Estimates Committee, ${ }^{64}$ the dramatic turnaround in Afghani refugees post-9/11 was due in a significant measure to changing conditions in that country. Hatton concludes that this "policy explains only abouta third of the steep decline between 2001 and 2006 - a distinctly smaller effect than some politicians

60 "Detainees to Leave Nauru”, Sydney Morning Herald, 13 Oct. 2005; HREOC, Submission, 4.16.

61 J. Phillips, "The 'Pacific Solution' Revisited: A Statistical Guide to the Asylum Seeker Caseloads on Nauru and Manus Island", Parliamentary Library Background Note, Parliament of Australia, Sep. 2012, Table 26, available at: http://www.aph.gov.au/About_Parliament/Parliamentary_Departments/Parliamentary_Library/ pubs/BN/2012-2013/PacificSolution (last visited 30 Aug. 2013); HREOC, Submission, 4.12.

62 HREOC, Submission, 4.13.

63 “Nauru Amending Laws for Refugee Determinations”, Australian Broadcasting Corporation, 8 Oct. 2012, available at: http://www.abc.net.au/news/2012-10-08/an-asylum-seekers-will-have-appeals-heard-in-nauru/ 4300298 (last visited 30 Aug. 2013).

64 J. Menadue, “The Pacific Solution Didn't Work Before and it Won't Work Now”, The Drum (Australian Broadcasting Corporation), 14 Mar. 2012, available at: http://www.abc.net.au/unleashed/3886792.html (last visited 30 Aug. 2013). 
have claimed" ${ }^{65}$ Indeed, since the resurrection of the Pacific Solution in 20112012 has corresponded to a steep rise in IMAs, it remains unclear just how effective deterrence actually is. ${ }^{66}$

\subsection{Collateral damage}

In relation to drug policy, "zero tolerance" assumes that no level of illicit use is acceptable; the only proper goal for law enforcement is to wipe it out. John Howard argued that "illicit drugs are highly dangerous, that there is no safe level of use, [and] that the only sensible objective is abstinence" ${ }^{67}$ Throughout the 1980s, the steady intensification of punitive laws, reverse onus provisions, financial appropriations, and other devices carved out a field of legal anomalies in which fundamental principles of justice were sidelined. ${ }^{68}$ The history of Australian drug policy highlights the collateral damage that such a cycle causes, first to the integrity of the Australian legal system, and secondly to those caught up in the law enforcement juggernaut.

The integrity of the Australian legal system is likewise being undermined by Australian asylum policy. In order to advance a zero tolerance model that aims to remove all IMAs from Australian jurisdiction, come what may, Australia has "excised" parts of Australian territory, thereby permitting their legal removal off-shore to places where they may be afforded significantly lesser protections than under domestic law. ${ }^{69}$ This strategy was perfected in May 2013 when legislation excised the whole of the Australian mainland for the purposes of immigration. ${ }^{70}$ In order, supposedly, to better protect us, governments around the world have, since 9/11, extended their capacity to exercise power unfettered by legal constraints or supervision. ${ }^{71}$ Guantanamo, which Lord Steyn famously described as a "legal black hole", ${ }^{72}$ is one such example. Under the Migration Amendment (Unauthorised Maritime Arrivals and Other Measures) Act the whole of Australia has been transformed into a "legal black hole" for refugees and asylum-seekers. ${ }^{73}$

65 Hatton, "The Rise and Fall of Asylum", F209.

66 Australian Government, DIAC, Asylum Statistics_Australia (Quarterly Tables), 1; B. Hall, "More Asylum Seekers Arrive”, Sydney Morning Herald, 27 Mar. 2013, available at: http://www.smh.com.au/federal-politics/ political-news/more-asylum-seekers-arrive-20130326-2gsa0.html (last visited 30 Aug. 2013).

67 Mendes, "Social Conservatism vs. Harm Minimisation", 6.

68 Manderson, From Mr Sin to Mr Big, 157-88.

69 Migration Amendment (Excision from Migration Zone) Act 2001 (Commonwealth of Australia).

70 Migration Amendment (Unauthorised Maritime Arrivals and Other Measures) Act 2013 (Commonwealth of Australia); L. Wilson, "Excision of Mainland Finally Made into Law", The Australian, 17 May 2013, available at: http://aap.newscentre.com.au/cpsunat/130517/library/human_rights/31093598.html (last visited 30 Aug. 2013)

71 G. Agamben, State of Exception, K. Attell trans., Chicago, University of Chicago Press, 2005.

72 J. Steyn, "Guantanamo: The Legal Black Hole", International and Comparative Law Quarterly, 53, 2004, 1-15.

73 S.D. Brophy, "Lawless Sovereignty: Challenging the State of Exception", Social and Legal Studies, 18(2), 2009, 199; E. Guild, Security and European Human Rights: Protecting Individual Rights in Times of Exception and Military Action, Nijmegen, Wolf Legal Publishers, 2007; E. Guild, Security and Migration in the 21st 
The other side of the collateral damage caused by zero tolerance is the harm done by aggressive law enforcement. Again, the parallel with drug policy is fruitful. Footage of spectacular customs hauls were a familiar sight on television news in the 1990s, but these dramatic actions failed to make any lasting inroads into the drug trade. Drug smuggling became slightly riskier. Drugs therefore became more expensive, the drug trade more lucrative and violent, and pushers and users more dependent on enlisting new clients or stepped up the crime needed to support their habits - a classic example of a vicious circle in which tough law enforcement policies exacerbate the very problems they were meant to eradicate. Those with the least choice always suffer the most at the hands of a legal structure lashing out at its own impotence: members of the underclass in US cities, for example, or low-level couriers subject to the death penalty in places like Malaysia, Singapore, or Indonesia. ${ }^{74}$

Aggressive interdiction strategies are likewise a mainstay of Australian asylum policy - Operation Relex, as it was known in the years after 2000, and now the "Bali Process". ${ }^{75}$ But, like the occasional heroin raid, such actions leave the underlying problems and pressures quite untouched. The Australian Government has provided significant funds over the years to support "people smuggling disruption activities", including by infiltrating smuggling rings, confiscating and even sabotaging boats. ${ }^{76}$ Despite arguments to the contrary, ${ }^{77}$ the public discourse that people smuggles are "vermin" who should "rot in hell" continues to predominate - family members in Sri Lanka, Pakistani travel agents, poor Indonesian fishermen, vermin one and all.

Inevitably, however, severe penalties and confiscating boats only encourage smugglers to minimise their economic risk and to maximise their profit. Vessels are increasingly unseaworthy and overcrowded, manned by inexperienced and impoverished young Indonesians - only increasing the risk of a tragedy at sea. On 25 March 2013, two asylum-seekers died as a result of the inexperience of the "sailors" who were handling their boat after it was boarded by Australian officials. $^{78}$ We suppose that if we make smuggling dangerous enough, asylumseekers will just say no. We should know from our experience with drug users and drug smuggling that this is just not so.

Century Polity, Cambridge, Cambridge University Press, 2009; P.K. Rajaram \& C. Grundy-Warr, "The Irregular Migrant as Homo Sacer: Migration and Detention in Australia, Malaysia and Thailand", International Migration, 42(1), 2004, 33.

74 Linton, Cocaina.

75 Fourth Bali Regional Ministerial Conference on People Smuggling, Trafficking in Persons and Related Transnational Crime, Mar. 2011.

76 A. Millbank, "Kind or Cruel?: Labor's Boat People Policies", People and Place, 17(4), 2009, 12-13; Kevin, Reluctant Rescuers.

77 R. de Crespigny, The People Smuggler, Harmondsworth, Penguin, 2012.

78 M. Gordon \& J. Swan, "Asylum Seekers Drown with Officials on Board", Sydney Morning Herald, 26 Mar. 2013, available at: http://www.smh.com.au/federal-politics/political-news/asylum-seekers-drown-with-offi cials-on-board-20130325-2gqd6.html (last visited 30 Aug. 2013). 


\section{Harm reduction}

\subsection{New directions}

Drug history offers more than a cautionary tale of misplaced zeal. Recent years have seen a dramatic decline in the use of overblown rhetoric in many developed countries around the world, accompanied by a gradual shift from a policy of "zero tolerance" to one of "harm reduction". Zero tolerance assumes that any level of drug use in society is unacceptable. Policies that help drug users live better lives or avoid prison are seen as misguided. Illegal drugs are framed as a law and order problem. But harm reduction strategies assume the opposite. They argue that some level of drug use in society is inevitable. Policies should therefore not aim to eliminate drug use entirely, but instead concentrate on modifying the dangerous conditions under which drugs are taken. Illegal drugs are reframed as a health problem. ${ }^{79}$

In this trend, Australian policy has led the world. ${ }^{80}$ The moral panic of the recent past sometimes seems like a dim memory. The possession or growing of cannabis for personal use has been decriminalised in three Australian jurisdictions, ${ }^{81}$ with demonstrable benefits to users and to the legal system. Elsewhere, conviction for small levels of personal use is increasingly uncommon. All Australian jurisdictions now make extensive use of "cannabis cautioning schemes" to avoid prosecution and/or divert users to education or counselling programmes. In May 2013, a New South Wales Parliamentary Committee unanimously recommended the legalisation of the medical use of cannabis. ${ }^{82}$ Such a move would have been unthinkable 10 years ago.

Meanwhile, court-based schemes frequently divert heroin users to treatment. Despite the continuing illegality of heroin, needle exchanges have been running successfully in Sydney, Melbourne, and elsewhere for years. The public health outcomes have been impressive. Australia has one of the lowest rates of HIV/AIDS prevalence among injecting drug users in the world. ${ }^{83}$ Clearly these

79 A. Wodak, Demand Reduction and Harm Reduction, Geneva, Global Commission on Drug Policies, 2011, available at: http://www.globalcommissionondrugs.org/wp-content/themes/gcdp_v1/pdf/Global_Com_ Alex_Wodak.pdf (last visited 30 Aug. 2013).

80 Wodak, Demand Reduction and Harm Reduction; Manderson, From Mr Sin to Mr Big, 181-198.

81 Controlled Substances (Expiation of Simple Cannabis Offences) Regulations 1987 (South Australia); Drug of Dependence Amendment Act 1992 (Australian Capital Territory); Misuse of Drugs Act Amendment Act 1996 (Northern Territory).

82 New South Wales Legislative Council General Purpose Standing Committee, The Use of Cannabis for Medical Purposes, Sydney, N.S.W. Parliament, 15 May 2013, x-xvi, available at: http://www.parliament. nsw.gov.au/Prod/Parlment/committee.

nsf/0/fdb7842246a5ab71ca257b6c0002f09b/\$FILE/Executive\%20summary\%20and\%20recommendations.pdf (last visited 30 Aug. 2013); A. Patty, "Cannabis Treatment for Pain Wins MPs' Approval”, Sydney Morning Herald, 15 May 2013, available at: http:/www.smh.com.au/nsw/cannabis-treatment-for-pain-winsmps-approval-20130515-2jlur.html (last visited 30 Aug. 2013).

83 P. Sendziuk, "Harm Reduction and HIV-Prevention Among Injecting Drug Users in Australia: An International Comparison", Canadian Bulletin of Medical History, 24(1), 2007, 113-29; D. Paone et al., "Syringe Exchange: HIV Prevention, Key Findings, and Future Directions", International Journal of Addiction, 30(12), 2005, 1647-1683; see W. Bowtell, "Applying the Paradox of Prevention", Griffith REVIEW: Staying Alive, 17, 2007, 5. 
programmes do not attempt to prohibit drug injection; instead they intend to regulate it better and make it safer. Australia's harm reduction policies have saved thousands of lives. In 2011, the Supreme Court of Canada unanimously held that denying addicts access to similar life-saving services violates the Canadian constitution. ${ }^{84}$ It is beginning to look like prohibition is losing the war it started.

What would a "harm reduction" policy in relation to IMAs look like? It would not seek to "stop the boats", but to stop the conditions which lead to them, and to alleviate the conditions of those on them. In the face of increasing refugee populations in the Asia-Pacific, and given the doubtful effectiveness of deterrence strategies, Australia is more dependent on best practices in other countries than they are on it. There can be no alternative but for the Australian Government to do as it would be done by - increasing the size of its resettlement programme from transit countries such as Malaysia and Indonesia, while encouraging those countries to accept more of the refugees now within its borders. Likewise, Australia must abandon the deterrence measures that have proven to be largely ineffectual. Mandatory detention facilities, off-shore processing centres, and the denial of the right to work and education are rhetorical gestures that do not protect Australia and do not discourage IMAs. They are mind-bogglingly counter-productive not only in terms of refugee health and safety, but also in terms of building viable regional relationships.

Indeed, funding detention centres and interdiction efforts in neighbouring countries is a classic example of the twisted logic of zero tolerance. Such measures only serve to make conditions worse for asylum-seekers in Indonesia and Malaysia - thereby directly causing more and more of them to try and reach Australia. Taking a leaf out of the harm-reduction handbook, Australia should increase its support for UNHCR operations and capacity-building in transit countries, and advocate to improve conditions for refugees in those countries, including by the legal recognition of the status of refugees and asylum-seekers, and supporting their right to work, education, and health. The irony is that only by treating IMAs better once they reach Australia can these arguments be credibly advanced, and the underlying causes behind their actions addressed.

Just as we have seen in relation to illegal drugs, laws undoubtedly have consequences - just not always the consequences we intended. Cutting access to family reunion programmes increases the number of children who drown at sea; prohibiting visa-holders from working creates an underclass; supporting interdiction and disruption activities overseas does not save lives, but costs them; failing to take more refugees now stores up a bigger problem for the future. The logic of "no advantage" drives conditions on Australia's off-shore ghettoes down, but creates political pressures that ultimately import unhealthy and discriminatory conditions back to Australian cities and suburbs. Meanwhile, the costs of zero tolerance spiral out of control, preventing money from being spent more

84 Canada (Attorney General) v. PHS Community Services Society [2011] 3 S.C.R. 134 (Supreme Court of Canada). 
wisely. Each turn of the screw only amplifies the errors. We have been down that road before.

\subsection{Changing course}

Australia's global leadership in the field of drug policy illustrates a lesson of enormous pragmatic importance: compassion and understanding are not just feel-good options. They are more effective social policy settings than anger and ignorance. The growing acceptance of harm reduction strategies provides a template to reframe the asylum debate by changing its goals and expectations. But what were the factors that allowed the seemingly interminable "drug wars" to subside? The imminent threat of HIV/AIDS brought together a small but influential group of "politicians, bureaucrats, advisers, doctors, nurses, nuns, sex workers, gay men, drug users, academics, journalists, advertising executives and social workers" around a pragmatic response that ended up saving many thousands of lives. ${ }^{85}$ For the first time, in fact, there really was a crisis. At that moment, the drug problem finally managed to break out of the populist rhetoric that had held it captive.

Two additional factors help explain the widespread acceptance that harm reduction drug policies gradually began to enjoy in Australia. The first element was the monstrous cost of the law enforcement system. Many economists, conservative as well as left-leaning, have extensively documented the irrationality and expense of drug prohibition. ${ }^{86}$

Despite minimal evidence of effectiveness, and abundant evidence of serious collateral damage, gold bars continue to rain down on drug law enforcement. It's just the opposite for drug treatment and harm reduction where there is substantial evidence of benefit and minimal evidence of serious collateral damage [...] In contrast to the money spent on law enforcement, the \$224 million spent in 2002-03 on drug treatment was an excellent investment. Methadone maintenance treatment saves between $\$ 4$ and $\$ 7$ for every dollar spent [...] The $\$ 32$ million spent on harm reduction in 2002-03 was also a great investment. Needle syringe programs save $\$ 4$ in health-care costs and $\$ 27$ overall for every dollar spent. ${ }^{87}$

In a political climate dominated by economic concerns - not moral or legal ones - such arguments are hard to ignore.

The second element was the "normalisation" of drug users. Stereotypes create anxiety, but personal contact reduces it. Throughout the 1980s and

85 Bowtell, "Applying the Paradox of Prevention", 1.

86 "Prohibition Could Be a False Economy", Sydney Morning Herald, 26 May 2012, available at: http://www. smh.com.au/national/prohibition-could-be-a-false-economy-20120525-1z9uc.html (last visited 30 Aug. 2013); Marks, "Prohibition or Regulation"; Miron, Drug War Crimes; A. Stevens, The Economy of Drug Policy, London, Routledge, 2006.

87 A. Wodak, "Get Smarter About Illicit Drugs to Help Balance the Budget", The Conversation, 2013, available at: http://theconversation.com/get-smarter-about-illicit-drugs-to-help-balance-the-budget-13841 (last visited 30 Aug. 2013). 
1990s, not only in Australia but in places like the US, Canada, and Great Britain, many people came in close contact with youth, in particular, who were suffering from the real physical and social consequences of drug laws. These people were not strangers; they were colleagues, friends, or loved ones. Stereotypes began to fall; punitive measures and a demonic rhetoric did not seem to either reflect reality or do any good. Groups became radicalized; the call for a more humane approach became more urgent. ${ }^{88}$ There is nothing so powerful as personal experience, even tragic experience, to wean people off the false comfort of conventional wisdom.

To what extent are these two elements present in relation to the "asylum problem problem"? The applicability of the first element, the economic implications of asylum policy, seems incontrovertible. The cost of mandatory detention and bridging visas is estimated at $\$ 375$ million per year. ${ }^{89}$ Deterrence and interdiction will cost Australia around $\$ 654$ million dollars over four years. ${ }^{90}$ Nauru will cost around $\$ 2$ billion over that time; Manus Island about $\$ 1$ billion more. ${ }^{91}$ The Government's recent Papua New Guinea policy is un-costed, unlimited, and likely to be once again in the billions. In comparison, Australia contributed $\$ 48$ million to UNHCR in 2012, a reduction of 13 per cent on the previous year. ${ }^{92}$

On the other hand, Australia's current political discourse does not provide much scope for the kind of normalisation that was the second element in tempering the "drug problem problem". Current policy makes it almost impossible for Australian citizens to interact with asylum-seekers on a daily basis. By excising the whole country from any relationship with asylum-seekers, segregating them behind razor wire and holding them thousands of miles off-shore, Australian policy makes it impossible for citizens to even see or hear them. This fanatical isolation is not only expensive and cruel. "Immunising" the community against any interaction perpetuates a culture of ignorance in which stereotypes are able to proliferate unchecked, ratcheting up the very anxiety that fuelled the "asylum problem problem" to begin with. This is yet another example of the perils of unintended consequences.

Australian policy is a classic example of the fantasies of zero tolerance. Drug policy history not only shows us the characteristic failures and dead-ends of this kind of thinking. It also points the way to alternative approaches in which compassion and pragmatism are revealed not to be opposites but partners.

88 See Friends and Families for Drug Law Reform, available at: http://www.ffdlr.org.au (last visited 30 Aug. 2013).

89 J. Kelly \& B. Packham, "Bob Carr Confirms Aid Budget Shift", The Australian, 18 Dec. 2012, available at: http://www.theaustralian.com.au/national-affairs/bob-carr-confirms-aid-budget-shift/story-fn59niix1226538662294 (last visited 30 Aug. 2013).

90 Millbank, “Kind or Cruel?”, 12.

91 “Australian Parliament to vote on Pacific Solution”, Radio Australia, 14 Aug. 2012, available at: http://www. abc.net.au/news/2012-08-14/an-asiapac-asylum-vote/4197232 (last visited 30 Aug. 2013).

92 UNHCR, Australia, undated, available at: http://www.unhcr.org/pages/49e487af6.html (last visited 30 Aug. 2013). 
Australians may yet appreciate how we are connected to the regional and global problems that now seem to surprise and bewilder us. Our understanding of the global circumstances of refugees may yet outweigh our long-standing defensive anxiety. Such a transformation would come not a moment too soon - but it would not, as it happens, be entirely without precedent. 